\title{
Microcytic Anemia
}

National Cancer Institute

\section{Source}

National Cancer Institute. Microcytic Anemia. NCI Thesaurus. Code C35141.

Anemia in which the red blood cell volume is decreased. 